ОГЛЯд

УДК 547.466.64-06:612.013

DOI 10.11603/mcch.2410-681X.2017.v0.i1.7685

А. В. Руцька, Н. В. Гецько, І. Я. Криницька

ТЕРНОПІЛЬСЬКИЙ ДЕРЖАВНИЙ МЕДИЧНИЙ УНІВЕРСИТЕТ ІМЕНІ І. Я. ГОРБАЧЕВСЬКОГО

\title{
ТОКСИЧНИЙ ВПЛИВ ГЛУТАМАТУ НАТРІЮ НА ЖИВИЙ ОРГАНІЗМ (ОГЛЯД ЛІТЕРАТУРИ)
}

У статті проаналізовано наявні літературні дані щодо проблеми застосування харчових добавок у харчовій промисловості. На думку багатьох учених, зменшення кількості свіжих харчових продуктів, що споживаються в їжу, та збільшення штучних добавок можуть бути однією з причин підвищення поширеності таких захворювань, як рак, цукровий діабет, ожиріння, депресія і бронхіальна астма.

Кількість харчових добавок, які застосовують у виробництві харчових продуктів у різних країнах, досягає сьогодні п'ятисот, не враховуючи комбінованих добавок та ароматизаторів. Однією 3 найпоширеніших харчових добавок як в Україні, так і в Європі є глутамат натрію (E621). Дослідження показали, що надлишок глутамату натрію може провокувати розвиток гіпертонії та інсультів, цукрового діабету, хвороби Альцгеймера й аномалії розвитку нервової системи, ерозійних уражень слизової оболонки шлунка та збільшення маси тіла.

На сьогодні немає достовірних даних, що показували б, в яких дозах і за яких умов глутамат натрію, що споживається в їжу постійно, шкідливий для здоров'я. Існують дослідження про те, що приймання глутамату натрію в кількості 3 г на день не безпечне для здоров'я людини. Проте інші дослідники стверджують, що щоденне введення щурам глутамату натрію навіть у безпечних для здоров'я людини дозах (15 і 30 мг/кг, що відповідає 1 й 2 г на середньостатистичну людину) має токсичний вплив.

Отже, спираючись на велику кількість даних, можна стверджувати, що сьогодні відбувається постійне збільшення використання харчових добавок у харчовій промисловості як економічно розвинених країн, так і країн, що розвиваються. I оскільки харчові добавки є чужорідними для організму людини речовинами (за хімічним складом або кількістю), особливої актуальності набувають дослідження впливу харчових добавок на стан здоров'я людини. Даних про біохімічні та морорологічні зміни в основних системах і органах організму вкрай мало, тому виникає необхідність детально вивчити цю проблему. Крім того, варто акцентувати увагу не лише на дослідженні встановлених небезпечних доз харчових добавок, але і на вивченні молекулярних механізмів впливу “безпечних" (дозволених) доз цих речовин на живий організм.

КЛЮчОВІ СЛОВА: харчові добавки; глутамат натрію; токсичність.

Відмітною особливістю сучасних харчових технологій є використання харчових добавок, які виконують технологічні фрункції, поліпшують органолептичні властивості харчових продуктів і не завжди є безпечними для здоров'я людини [2].

До харчових добавок (food additives), за одним із перших визначень об'єднаного Кодексного комітету експертів ВОО3, належать "нехарчові речовини, що додаються в продукти харчування, як правило, в невеликих кількостях, для покращення зовнішнього вигляду, смакових якостей, текстури або для збільшення термінів зберігання". Сьогодні "харчові добавки" - це природні або штучні речовини чи їх сполуки, які спеціально вводять у харчові продукти в проце(с) А. В. Руцька, Н. В. Гецько, І. Я. Криницька, 2017. сі їх виготовлення 3 метою надання їм певних властивостей і/або збереження якості харчових продуктів [12].

Виготовлення харчових продуктів у промислових масштабах привело до того, що хімічні добавки стали частиною нашого щоденного раціону. На думку багатьох учених, зменшення кількості свіжих харчових продуктів, що споживаються в їжу, та збільшення штучних добавок можуть бути однією з причин підвищення поширеності таких захворювань, як рак, цукровий діабет, ожиріння, депресія і бронхіальна астмa [3].

Кількість харчових добавок, які застосовують у виробництві харчових продуктів у різних країнах, досягає сьогодні п'ятисот, не враховуючи 
комбінованих добавок, ароматизаторів. Для гармонізації їх використання Європейська рада розробила раціональну систему цифррової кодифрікації харчових добавок з літерою "E" [3, 12]:

1. Е100-E182 - харчові барвники. Відновлюють колір продукту, втрачений при переробці. Можуть бути природними, як бета-каротин, або хімічними, як тартразин.

2. E200-E299 - консерванти. Відповідають за безпеку товарів, запобігаючи розмноженню бактерій або грибків.

3. Е300-Е399 - антиоксиданти. Захищають продукти харчування від окиснення, прогірклості й зміни кольору. $€$ як природними сполуками (аскорбінова кислота, вітамін Е), так і хімічно синтезованими.

4. E400-E499 - стабілізатори консистенції, емульгатори. Зберігають консистенцію продуктів, покращують їх в'язкість (наприклад, пектин E440).

5. Е500-E619 - регулятори кислотності, розпушувачі.

6. Е620-E699 - підсилювачі смаку й аромату.

7. E700-E800 - запасні індекси для іншої можливої інфрормації.

8. E900-E999-глазуруючі агенти, поліпшувачі хліба.

\section{Харчові добавки, які найчастіше використовують в Україні}

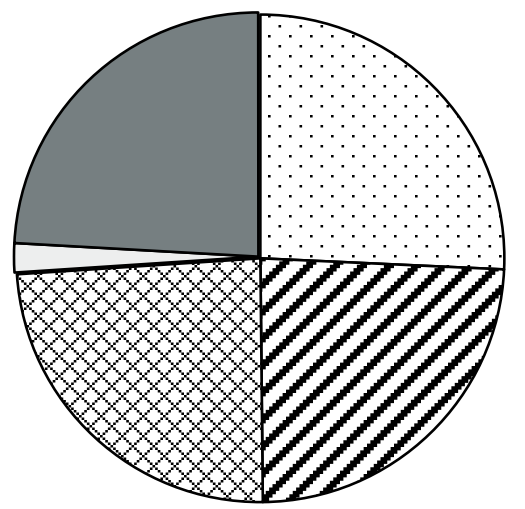

๑E621 - глутамат натрію однозаміщений

Q E260 - оцтова кислота

$\square$ E211 - бензоат натрію

口ЕЗ30 - лимонна кислота

口E1442 - гідроксипропілдикрохмальфосфат

\section{Харчові добавки, які найчастіше використовують в Європі}

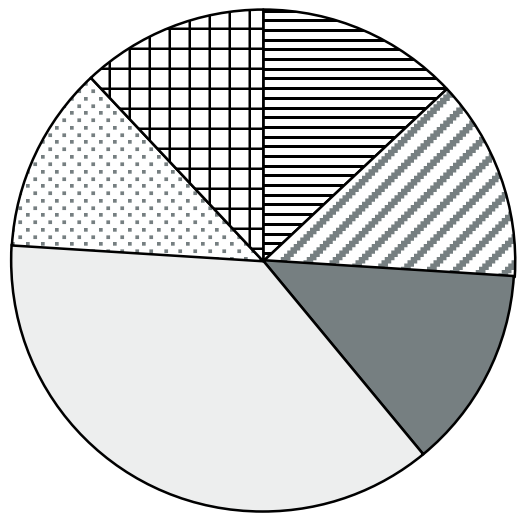

ĐE471 - моногліцериди і дигліцериди жирних кислот

$\square \mathrm{E} 412$ - гуарова камідь

口E1442 - гідроксипропілдикрохмальфосфат

口Е330 - лимонна кислота

๑621 - глутамат натрію однозаміщений

DE407 - каррагінан і його солі 
страв з м'яса, риби, птиці, овочів, бобових, соусів, варених ковбасних виробів, консервів, напівфрабрикатів, салатів, приправ [6, 10].

Хімічна фрормула речовини: $\mathrm{C}_{5} \mathrm{H}_{8} \mathrm{NNaO}_{4}$ (рис. 2).<smiles>N[C@@H](CCC(=O)O)C(=O)[O-]</smiles>

Рис. 2. Хімічна структура мононатрієвої солі глутамінової кислоти

Харчова добавка Е621 має вигляд твердого білого кристалічного порошку, який при контакті з водою розпадається на катіони натрію та аніони глутамату. Окиснювальне дезамінування глутамінової кислоти відбувається під впливом ферменту глутаматдегідрогенази в мітохондріях печінки (а також інших органів) з утворенням аміаку, НАДН+H+ $\mathrm{\alpha}$-кетоглутарової кислоти, яка може бути використана у циклі лимонної кислоти. Ця реакція $€$ основним джерелом аміаку в організмі людини. 3 глутамату синтезуються амінокислоти глутамін, пролін, орнітин. У мозку $€$ високоактивна глутаматдекарбоксилаза, яка каталізує декарбоксилювання глутамату до гамма-аміномасляної кислоти. Також глутамат входить до складу трипептиду глутатіону. Глутамін синтезується з глутамату під дією глутамінсинтетази, а під впливом глутамінази розщеплюється знов до глутамату й аміаку, що забезпечує фрункцію глутаміну для перенесення аміаку. Крім того, глутамін як донор амідного азоту бере участь у синтезі пуринів і піримідинів, гексозамінів, аспарагіну [8].

Стимулюючи закінчення смакових нервів, глутамінова кислота таії солі підсилюють смакові відчуття (смакові рецептори людини відчувають присутність глутамату натрію при його розчиненні у воді в співвідношенні 1:300), в результаті чого з'являється відчуття задоволеності.

Вперше глутамат натрію виділив у 1907 p. профресор Токійського імперського університету Кікунае Ікеда шляхом гідролізу пшеничного білка, він виявив його здатність посилювати природні смакові якості їжі, які втрачаються при обробці та зберіганні [5].

Глутамат натрію в Китаї відомий як "смакова приправа”, в Японії - як “чудовий порошок” (“фецзин"). Смак глутамату називають "умами", що $€$ одним з основних смакових відчуттів, відомих людині. Дану харчову добавку отримують як 3 натуральних ресурсів, так і за допомогою хімічних реакцій. Глутамат натрію зовні схожий на сіль або цукор, але має інший смак, на Заході про нього говорять "savory" - бульйоноподібний чи м'ясний смак [3].
Добова доза споживання глутамату натрію для дорослих не повинна перевищувати 1,5 г у середньому, для підлітків - не більше 0,5 г. Дітям до трьох років споживати продукти з вмістом глутамату натрію не рекомендують [7]. Згідно 3 результатами спільного дослідження урядів Австралії та Нової Зеландії у 2003 р., типова їжа з китайського ресторану містить між 10 і 1500 мг глутамату натрію на 100 г [24]. Оральна доза, що є летальною для $50 \%$ осіб $\left(\mathrm{LD}_{50}\right)$, у щурів та мишей становить 15 000-18 000 мг/кг маси тіла [25, 36].

За оцінками експертів, середня добова доза глутамату натрію для людини в промислово розвинених країнах становить 0,3-1,0 г, але це залежить від вмісту глутамату натрію у продуктах харчування і смакових переваг індивідуума [25].

В Україні глутамат натрію став легальною харчовою добавкою тільки у 2000 р. після прийняття Постанови Кабінету Міністрів України від 17 лютого № 342, згідно з якою його внесли до переліку дозволених в Україні харчових добавок. При додаванні глутамату натрію в харчові продукти (до 10 г/кг) підсилюються їх природні смакові властивості, послаблені в процесі переробки і зберігання, маскуються окремі негативні складові смаку й запаху. Зазвичай глутамат натрію використовують для посилення смаку та аромату у виробництві сухих супів, бульйонів, продуктів швидкого приготування, чіпсів, крекерів, соусів, майонезів, кетчупів, м'ясопродуктів, консервованих море- і рибопродуктів у кількості від 0,1 до 0,5 \% [2].

Сумніви, що стосуються безпеки споживання харчової добавки - глутамату натрію з'явилися в 1968 р. після опублікування в англійському медичному журналі даних про те, що натрієва сіль глутамінової кислоти може спричиняти багато хвороб [19]. Дані захворювання було об'єднано терміном "синдром китайського ресторану", симптомами якого $є$ різкий біль у шлунку, грудях або голові, почервоніння обличчя, підвищена температура тіла, посилення потовиділення [34]. Після цих публікацій протягом майже 50 років аж до сьогодні навколо даного питання тривають жваві дискусії [24]. У багатьох країнах проведено велику кількість досліджень як на здорових добровольцях, так і на людях, які вважають себе чутливими до глутамату натрію. Незважаючи на значне число робіт, присвячених даній проблемі, єдиної думки щодо безпечної дози поширеної харчової добавки - глутамату натрію немає [24, 31, 35].

Глутамат натрію при систематичному його споживанні у великій кількості спричиняє так званий "синдром китайського ресторану": почервоніння обличчя, шиї, ділянки рота, прискорене серцебиття, головний біль. Крім того, вста- 
новлено, що харчова добавка E621 пошкоджує клітини мозку, підвищує ризик розвитку хвороби Альцгеймера, а також викликає наркотичне звикання, в тому числі й у дітей, сприяючи переїданню. Оскільки виробник, погнавшись за прибутком, активно додає в їжу підсилювач смаку - глутамат натрію, споживач часто переходить на незбалансовану їжу 3 надлишком калорій, що позначається як на його масі, так і на здоров'ї травного тракту [2].

Деякі вчені стверджують, що глутамат натрію у вигляді харчової добавки може бути однією 3 причин розвитку ожиріння, а також викликає порушення обміну речовин $[13,21]$. Глутамат посилює апетит та зумовлює гіперфрагію [16]. Встановлено, що введення глутамату натрію новонародженим щурам спричиняє руйнування вентромедіального і дугоподібних (аркуатних) ядер гіпоталамуса, що призводить до розвитку ожиріння в дорослих щурів з відсутністю контролю між поглинанням їжі й витратами енергії [26]. Проте інші дослідники $[32,33]$ доводять, що споживання глутамату натрію навіть у великих дозах не шкодить організму людини.

На сьогодні немає достовірних даних, що показували б, в яких дозах і за яких умов глутамат натрію, що споживається в їжу постійно у вигляді добавки E621, шкідливий для здоров'я [1]. Існують дослідження про те, що приймання глутамату натрію в кількості 3 г на день не безпечне для здоров'я людини [31, 35]. Проте деякі вчені стверджують, що щоденне введення щурам глутамату натрію навіть у безпечних для здоров'я людини дозах (15 і 30 мг/кг, що відповідає 1 й 2 г на середньостатистичну людину) протягом 20-ти і 30-ти днів призводило до подразнення слизової оболонки шлунка, що проявлялося розвитком крововиливів, ерозій та виразок, збільшення базальної секреції соляної кислоти і маси тіла [14].

Дія глутамату на головний і спинний мозок ссавців відома 3 50-х років минулого століття, але лише в кінці 70-х стало зрозуміло, що він $€$ найважливішим збудливим нейромедіатором центральної нервової системи. Водночас було висловлено припущення, що глутамат діє на постсинаптичні рецептори [9, 23, 29].

Ученим вдалося відкрити молекулярний сигнальний механізм, що дає старт мієлінізації нейронів. Було з'ясовано, що початок процесу мієлінізації спричиняє активне виділення аксоном глутамату. Відомо, що за фоорування мієлінової оболонки аксонів у ЦНС відповідають сусідні клітини - олігодендроцити [11]. В ході численних експериментів доведено, що в певній концентрації глутамат може викликати перезбудження і некроз нервових клітин [17].
За результатами деяких досліджень, вільні солі глутамінової кислоти дуже швидко всмоктуються в шлунково-кишковому тракті, що може спричинити різкі стрибки концентрації глутамату натрію в плазмі крові. Деякі вчені стверджують, що такі піки можуть несприятливо впливати на нейрони, призводячи або до судомної активності, або до депресії. Введення новонародженим дитинчатам щурей або мишей (0-14 днів) глутамату у великих дозах орально або інтраперитонеально зумовлює гостру нейрональну дегенерацію гангліозних клітин сітківки і різних перивентрикулярних структур мозку $[22,27]$, проте автори інших робіт такого не відзначили [20].

W. J. Pizzi та співавтори встановили, що введення великих доз глутамату натрію може сприяти зниженню фертильності в мишей. Введення досліджуваної речовини тваринам у неонатальний період (від 2 до 11 днів) призвело до ряду еоректів, які проявлялися до періоду зрілості. Репродуктивну дисфункцію спостерігали як у самців, так і в самок. Самки мишей, уражені глутаматом, рідше приносили потомство, послід був меншим, самці демонстрували зниження плодючості. В експериментальних тварин спостерігали збільшення маси тіла та зменшення маси гіпофріза, щитоподібної і статевої залоз [9, 30].

Вчені з японського Університету Хіросакі (Hirosaki University, Japan) 3'ясували, що щури, які перебували на дієті з високим вмістом глутамату, страждали від втрати зору через стоншування сітківки. За їх словами, це перше дослідження, яке показує, що пошкодження очей може бути викликане споживанням їжі, яка містить глутамат [9, 28].

Згідно 3 дослідженням "The INTERMAP Cooperative Research Group”, проведеним на 752 здорових мешканцях Китаю (з них 48,7 \% жінок) віком 40-59 років, випадковим чином відібраних з трьох сіл на півночі й півдні Китаю, приймання глутамату натрію збільшує ймовірність мати зайву масу $[9,15]$. Однак отримані дані оскаржили інші дослідники. Відповідно до результатів нових досліджень, було виявлено зворотний зв'язок між споживанням глутамату і 5-відсотковим збільшенням маси тіла $(P=0,028)$. Але коли модель скоригували на споживання рису або інші схеми живлення, цей зв'язок скасували. Отримані результати показали, що, коли були враховані інші продукти харчування або раціон харчування, ніякого зв'язку між споживанням глутамату і збільшенням маси не спостерігали [18].

В. В. Бевзо встановив, що тривале введення (протягом 4-х тижнів) щурам 3 \% розчину глутамату натрію в дозі 30 мг/кг маси тіла призводить до підвищення вмісту в сироватці крові загальних і тирозиновмісних пептидів, речовин низької та 
середньої молекулярної маси, а також зростання значень коесріцієнта інтоксикації, що опосередковано вказує на порушення процесів детоксикації ендогенних метаболітів у печінці тварин [1].

М. В. Гончаренко та співавтори з'ясували: використання глутамату натрію в процесі засолу оселедця призводить до зрушення величини значення рН м'язової тканини в кислу сторону на 0,3-0,6 одиниці; глутамат натрію проникає в м'язову тканину оселедця протягом 4-х діб зберігання; досліджена кількість глутамату натрію сприяє зниженню чисельності мікроорганізмів у солоній рибопродукції за рахунок зміни величини значення рН м'язової тканини в кислу зону. Глутамат натрію уповільнює розвиток мікрококів, бактерій роду Bacillus, слабко впливає на бактерії роду Sarcina, не впливає на інтенсиорікацію процесу гідролізу білків солоного оселедця [6].

А. О. Бороденко та співавтори проводили дослідження на 20 безпородних щурах різної статі у складі 4 досліджуваних груп. щурам основної групи вводили перорально 2 мл 20 \% розчину глутамату натрію з розрахунку 3 г/кг маси тіла тварини. Це вдвічі перевищувало добову норму, яку отримували тварини контрольної групи. Вчені виявили, що приймання всередину глутамату натрію в межах рекомендованих доз не викликає виражених патологічних змін у слизовій, м'язовій та серозній оболонках стінки шлунка, але спостерігали незначне повнокров'я судин підслизової оболонки. Було з'ясовано, що у високих дозах глутамат натрію чинить місцеву патогенну дію на тканини шлунка, що полягає у стоншенні всіх шарів стінки шлунка, десквамації слизової оболонки та її дезорганізації у вигляді зменшення розміру шлункових залоз, збільшення кількості судин та їх повнокров'я. Одним із механізмів патогенного впливу глутамату натрію $€$ контактна місцева та вільнорадикальна окиснювальна дія на тканини шлунка [4].

Отже, спираючись на велику кількість даних, можна стверджувати, що сьогодні відбувається постійне збільшення використання харчових добавок у харчовій промисловості як економічно розвинених країн, так і країн, що розвиваються. І оскільки харчові добавки є чужорідними для організму людини речовинами (за хімічним складом або кількістю), особливої актуальності набувають дослідження впливу харчових добавок на стан здоров'я людини. Даних про біохімічні та морфологічні зміни в основних системах і органах організму вкрай мало, тому виникає необхідність детально вивчити цю проблему. Крім того, варто акцентувати увагу не лише на дослідженні встановлених небезпечних доз харчових добавок, але і на вивченні молекулярних механізмів впливу “безпечних" (дозволених) доз цих речовин на живий організм.

\section{СПИСОК ЛІТЕРАТУРИ}

1. Бевзо В. В. Дослідження токсодинаміки глутамату натрію на організм щурів за умов тривалого його введення / В.В.Бевзо // Клініч. та експерим. патологія. - 2016. - 15, № 2 (56), ч. 2. - С. 13-16.

2. Бельтюкова С. В. Определение глутамата натрия методом тонкослойной хроматографии с люминесцентным детектированием / С. В. Бельтюкова, Е. В. Малинка // Вісн. ОНУ. Хімія. - 2016. - 21, № 1 (57). - С. 50-58.

3. Бибик Е. Ю. Анализ спектра пищевых добавок в продуктах питания / Е. Ю. Бибик, Э. А. Яровая // Укр. мед. альм. - 2011. - 14, № 2. - С. 20-22.

4. Бороденко А. О. Вплив глутамату натрію на стінку шлунка щурів за умов корегувального впливу токофреролу та альмагелю / А. О. Бороденко, А. О. Потапова, Р. Ф. Наумко // Актуальні питання теоретичної медицини. Актуальні питання клінічної медицини. Клінічні та патогенетичні аспекти мікроелементозів : матеріали наук.-практ. конор. студентів, молодих вчених, лікарів та викладачів (Суми, 20-22 квіт. 2011 р.) / відп. за вип. Л. Н. Приступа. - Суми : СумДУ, 2011. Ч. 1. - С. 54.

5. Влияние глипролинов на структурно-срункциональное состояние слизистой оболочки желудка и массу тела крыс в условиях длительного введения глутамата натрия / Т. М. Фалалеева, Г.Е.Самонина, Т. В. Береговая [и др.] // Физика живого. - 2010. - 18, № 1. - С. 154-159.

6. Влияние глутамата натрия на развитие микрофрлоры и биохимические свойства соленой сельди / М. В. Гончаренко, Д. А. Тюрина, М. Н. Альшевская, В. И. Шендерюк // Вестн. АГТУ. Серия "Рыбное хозяйство". - 2011. - № 2. - С. 143-147.

7. Воробьев В. В. Вредное воздействие пищевых добавок на безопасность морепродуктов и здоровье населения / В. В. Воробьев // Рыбное хозяйство. 2008. - № 5. - C. 8-11.

8. Гонський Я. І. Біохімія людини : підручник / Я. І. Гонський, Т. П. Максимчук, М. І. Калинський. Тернопіль : Укрмедкнига, 2002. - 744 с. 
9. Дубовая Г. А. Влияние глутамата натрия на живые организмы / Г. А. Дубовая, Ю. Н. Дубовая, Д. П. Татаренко // Вісн. ЛНУ імені Тараса Шевченка. 2013. - № 19 (278), ч. 1. - С. 149-154.

10. Исупов В. П. Пищевые добавки и пряности. История, состав и применение / В. П. Исупов. - СПб. : ГИОРД, 2000. - 176 с.

11. Караваев Е. Н. Влияние глутамата на активность нейронов медиальной септальной области in vitro / Е. Н. Караваев, И. Ю. Попова, В. Ф. Кичигина // Фундаментальные исследования. - 2005. - № 3. С. $18-22$.

12. Маюрникова Л. А. Пищевые и биологически активные добавки : учеб. пособ. / Л. А. Маюрникова, М. С. Куракин. - Кемерово : Кемеровский технологический институт пищевой промышленности, 2006. $124 \mathrm{c.}$

13. Фалалєєва Т. М. Зміни маси тіла щурів за умов довготривалого введення глутамату натрію / Т. М. Фалалєєва // Світ медицини та біології. - 2012. - № 2. C. $170-172$.

14. Фалалєєва Т. М. Вплив тривалого введення глутамату натрію на структурно-фрункціональний стан шлунка у щурів / Т. М. Фалалєєва, В. М. Кухарський, Т. В. Берегова // Фізіол. журн. - 2010. - 56, № 2. C. 201.

15. Zhao K. L. Association of monosodium glutamate intake with overweight in Chinese adults: the INTERMAP Study / K. L. Zhao, M. L. Daviglus // Obesity. -2008. -16, № 8. - P. 1875-1880.

16. Dawson R. Attenuation of leptin-mediated effects by monosodium glutamate-induced arcuate nucleus damage / R. Dawson, M. A. Pelleymounter // Journal of Physiology. - 1997. - 273. - P. 202-206.

17. Brian S. M. Glutamate as a neurotransmitter in the brain: review of Physiology and Pathology / S. M. Brian // Journal of Nutrition. - 2000. - 130. P. 1007-1015. 18. Consensus meeting: monosodium glutamate-an update / K. Beyreuther, H. K. Biesalski, J. D. Fernstrom [et al.] // Journal of Clinical Nutritional. 2007. - 61. - P. 304-313.

19. Davies N. E. Chinese-restaurant syndrome / N. E. Davies // Journal of Medicine. - 1968. - 278, № 20. $1124 \mathrm{p}$.

20. Differential developmental expression of the two rat brain glutamate transporter proteins GLAST and GLT / K. Ullensvang, K. P. Lehre, J. Storm-Mathisen [et al.] // Journal of Neuroscience. - 1997. - 9. - P. 1646-1655.

21. Effect of food restriction on energy expenditure of monosodium glutamate-induced obese rats / J. Luz, V. P. Pasin, D. J. Silva [et al.] // Journal of Nutritional Metabolism. - 2010. - 56, No. 1. - P. 31-35.

22. Excitotoxins: an overview / J. W. Olney, K. Fuxe, P. Roberts, R. Schwarcz // Excitotoxins. - London, UK : Macmillan Press. - 1983. - P. 82-96.

23. Farombi E. O. Monosodium glutamate-induced oxidative damage and genotoxicity in the rat: modulatory role of vitamin C, vitamin E and quercetin / E. O. Farombi, O. O. Onyema // Journal of Human Experimental Toxicology. - 2006. - 25 (5). - P. 251-259.

24. Freeman M. Reconsidering the effects of monosodium glutamate: a literature review / M. Freeman // Journal of American Academician Nurse Practice. 2006. - 18, № 10. - P. 482-486.

25. Husarova V. Monosodium glutamate toxic effects and their implications for human intake: a review / V. Husarova, D. Ostatnikova // Journal of Medical Internet Research. - 2013. - 2013. - P. 1-12.

26. Lorden J. F. Behavioral and endocrinological effects of single injections of monosodium glutamate in the mouse / J. F. Lorden, A. Caudle // Journal of Neurobehavioral Toxicology Teratology. - 1986. - 8, № 5. P. 509-519.

27. Meldrum B. Amino acids as dietary excitotoxins: a contribution to understanding neurodegenerative disorders / B. Meldrum // Journal of Brain Research Reviews. - 1993. - 18. - P. 293-314.

28. Ohguro H. Too much MSG could cause blindness / $\mathrm{H}$. Ohguro // Journal of Experimental Eye Research. - 2001. - 75. - P. 307-315.

29. Olds J. Positive reinforcement produced by electrical stimulation of septal area and other regions of rat brain / J. Olds, P. Milner // Journal of Comparative and Physiological Psychology. - 1954. - 47. - P. 419 427.

30. Pizzi W. J. Monosodium glutamate administration to the newborn reduces reproductive ability in female and male mice / W. J. Pizzi, J. E. Barnhart, D. J. Fanslow // Journal of Science. - 1977. - 196. - P. 452-454.

31. Review of alleged reactions to monosodium glutamate and outcome of a multicenter doubleblind placebo-controlled study / R. Geha, A. Beiser, C. Ren [et al.] // Journal of Nutritional. - 2000. - 130. - P. 10581062.

32. Samuels A. Monosodium glutamate is not associated with obesity or a greater prevalence of weight gain over 5 years: findings from the Jiangsu Nutrition Study of Chinese adults - comments by Samuels / A. Samuels // Journal of Nutritional. - 2010. - 9. - P. 11-13.

33. Tarasoff L. Monosodium L-glutamate: A doubleblind study and review / L. Tarasoff, M. F. Kelly // Journal of Food and Chemical Toxicology. - 1993. - 31. P. 1019-1035.

34. The Chinese restaurant syndrome / O. J. C. García, C. Moyano, J. L. Fonseca, J. Bellido // Journal of Medicine Clinical. - 1996. - 107, № 13. - P. 518.

35. The monosodium glutamate symptom complex: assessment in a double-blind, placebo-controlled, randomized study / W. H. Yang, M. A. Drouin, M. Herbert [et al.] // Journal of Allergy Clinical Immunology. - 1997. 99. - P. 757-762.

36. Walker R.The Safety Evaluation of Monosodium Glutamate / R. Walker, J. R. Lupien // Journal of Nutrition. - 2000. - P. 1049-1052. 


\section{REFERENCES}

1. Bevzo, V.V. (2016). Doslidzhennia toksodynamiky hlutamatu natriiu na orhanizm shchuriv za umov tryvaloho yoho vvedennia [Research of toxicodynamics sodium glutamate in rats under prolonged its introduction]. Klinichna ta eksperementalna patolohiia - Clinical and Experimental Pathology, 2(56), 13-16 [in Ukrainian].

2. Beltiukova, S.V. (2016). Opredelenie glutamata natriia metodom tonkosloinoi khromatografii s liuminestsentnym detektirovaniem [Determination of monosodium glutamate thin-layer chromatography method with detection fluorescent]. Visnyk ONU. Khimiia - Journal of ONU. Chemistry, 1 (57), 50-58 [in Russian].

3. Bibik, E.Yu. \& Yarovaya, E.A. (2011). Analiz spektra pishchevykh dobavok v produktakh pitaniia [Spectral analysis of food additives in foods]. Ukrainskyi medychnyi almanakh - Ukrainian Medical Almanac, 2, 20-22 [in Russian].

4. Borodenko, A.O., Potapova, A.O. \& Naumko, R.F. (2011). Vplyv hlutamatu natriiu na stinku shlunka shchuriv za umov korehuvalnoho vplyvu tokoferolu ta almaheliu [Effect of sodium glutamate in the stomach wall rats under the influence of tocopherol and corrective almagel]. Aktualni pytannia teoretychnoi medytsyny. Aktualni pytannia klinichnoi medytsyny. Klinichni ta patohenetychni aspekty mikroelementoziv: materialy naukovo-praktych nykh konferentsii studentiv, molodykh vchenykh, likariv ta vykladachiv - Current Issues of Theoretical Medicine. Current Issues of Clinical Medicine. Clinical and Pathogenetic Aspects of Microelementosis Materials of Scientific Conferences of Students, Young Scientists, Doctors and Teachers. (p. 54). Sumy: SumDU [in Ukrainian].

5. Falaleeva, T.M., Samonina, G.E, Beregovaia, T.V., Dziubenko, N.V. \& Andreeva, L.A. (2010). Vliyanie gliprolinov na strukturno-funkttsionalnoe sostoianie slizistoi obolochki zheludka i massy tela krys v usloviiakh dlitelnogo vvedeniia glutamata natriia [The effect of glyprolines on the structural and functional state of the gastric mucosa and the body weight of rats under conditions of prolonged administration of sodium glutamate]. Fizika zhyvogo - Physics of living, 1, 154-159 [in Russian].

6. Goncharenko, M.V., Tiurina, D.A., Alshevskaya, M.N. \& Shenderiuk, V.I. (2011). Vliyanie glutamata natriya na razvitie mikroflory i biokhimicheskie svoystva solenoi seldi [Effect of sodium glutamate on the development of microflora and the biochemical properties of salted herring]. Vestnik AGTU - Journal of the State Technical University, 2, 143-147 [in Russian].

7. Vorobev, V.V. (2008). Vrednoe vozdeistvie pishchevykh dobavok na bezopasnost moreproduktov i zdorove naseleniya [Harmful effects of food additives on seafood safety and public health]. Rybnoe khoziaystvo-Fisheries, 5, 8-11 [in Russian].

8. Honskyi, Ya.I., Maksymchuk, T.P. \& Kalynskyi, M.I. (2002). Biokhimiia liudyny [Human Biochemistry]. Ternopil: Ukrmedknyha [in Ukrainian].

9. Dubovaya, G.A., Dubovaya, Yu.N. \& Tatarenko, D.P. (2013). Vliyanie glutamata natriya na zhivye organizmy [Effect of sodium glutamate on living organisms]. Visnyk LNU imeni Tarasa Shevchenka - Journal of LNU named after Taras Shevchenko, 19 (278), 149-154 [in Russian].

10. Isupov, V.P. (2000). Pishchevye dobavki i prianosti. istoriya, sostav i primenenie [Food additives and spices. History, composition and application]. SPb: GIORD [in Russian].
11. Karavaev, E.N., Popova, I.Yu. \& Kichigina, V.F. (2005). Vliyanie glutamata na aktivnost neyronov medialnoi septalnoi oblasti in vitro [Effect of glutamate on neuronal activity of the medial septal region in vitro]. Fundam. Issledovaniia - Fundamental Research, 3, 1822 [in Russian].

12. Mayurnikova, L.A. \& Kurakin, M.S. (2006). Pishchevye $i$ biologicheski aktivnye dobavki [Food and biologically active additives]. Kemerovo [in Russian].

13. Falalieieva, T.M. (2012). Zminy masy tila shchuriv za umov dovhotryvaloho vvedennia hlutamatu natriiu [Changes in body weight of rats under long-term administration of sodium glutamate]. Svit medytsyny ta biolohii - The World of Medicine and Biology, 2, 170-172 [in Ukrainian].

14. Falalieieva, T.M., Kukharskyi, V.M. \& Berehova, T.V. (2010). Vplyv tryvaloho vvedennia hlutamatu natriiu na strukturno-funktsionalnyi stan shlunka u shchuriv [The impact of prolonged administration of sodium glutamate on the structural and functional state of the stomach in rats]. Fiziolohichnyi zhurnal-Physiological Journal, 2, 201 [in Ukrainian].

15. Zhao, K.L. \& Daviglus, M.L. (2008). Association of monosodium glutamate intake with overweight in Chinese adults: the INTERMAP Study. Obesity, 16, 8, 1875-1880.

16. Dawson, R. \& Pelleymounter, M.A. (1997). Attenuation of leptin-mediated effects by monosodium glutamate-induced arcuate nucleus damage. Journal of Physiology, 273, 202-206.

17. Brian, S. M. (2000). Glutamate as a Neurotransmitter in the Brain: Review of Physiology and Pathology. Journal of Nutrition, 130, 1007-1015.

18. Beyreuther, K., Biesalski, H.K. \& Fernstrom, J.D. (2007). Consensus meeting: monosodium glutamate-an update. Journal of Clinical Nutritional, 61, 304-313.

19. Davies, N.E. (1968). Chinese-restaurant syndrome. Journal of Medicine, 278(20), 1124.

20. Ullensvang, K., Lehre, K. P. \& Storm-Mathisen, J. (1997). Differential developmental expression of the two rat brain glutamate transporter proteins GLAST and GLT. Journal of Neuroscience, 9, 1646-1655.

21. Luz, J., Pasin, V.P. \& Silva, D.J. (2010). Effect of food restriction on energy expenditure of monosodium glutamate-induced obese rats. Journal of Nutritional Metabolism, 56 (1), 31-35.

22. Olney, J. W., Fuxe, K., Roberts, P. \& Schwarcz, R. (1983). Excitotoxins: an overview. Macmillan Press, 82-96.

23. Farombi, E.O. \& Onyema, O.O. (2006). Monosodium glutamate-induced oxidative damage and genotoxicity in the rat: modulatory role of vitamin C, vitamin E and quercetin. Journal of Human Experimental Toxicology, 25 (5), 251-259.

24. Freeman, M. (2006). Reconsidering the effects of monosodium glutamate: a literature review. Journal of American Academician Nurse Practice, 18 (10), 482-486.

25. Husarova, V. \& Ostatnikova, D. (2013). Monosodium glutamate toxic effects and their implications for human intake: a review. Journal of Medical Internet Research, 2013 1-12.

26. Lorden, J.F. \& Caudle, A. (1986). Behavioral and endocrinological effects of single injections of monosodium glutamate in the mouse. Journal of Neurobehavioral Toxicology Teratology, 8 (5), 509-519. 
27. Meldrum, B. (1993). Amino acids as dietary excitotoxins: a contribution to understanding neurodegenerative disorders. Journal of Brain Research Reviews, 18, 293-314

28. Ohguro, H. (2001). Too much MSG could cause blindness. Journal of Experimental Eye Research, 75, 307-315.

29. Olds, J. \& Milner, P. (1954). Positive reinforcement produced by electrical stimulation of septal area and other regions of rat brain. Journal of Comparative and Physiological Psychology, 47, 419-427.

30. Pizzi, W.J., Barnhart, J.E. \& Fanslow, D.J. (1977). Monosodium glutamate administration to the newborn reduces reproductive ability in female and male mice. Journal of Science, 196, 452-454.

31. Geha, R., Beiser, A. \& Ren, C. (2000). Review of alleged reactions to monosodium glutamate and outcome of a multicenter double blind placebo-controlled study. Journal of Nutritional, 130, 1058-1062.
32. Samuels, A. (2010). Monosodium glutamate is not associated with obesity or a greater prevalence of weight gain over 5 years: findings from the Jiangsu Nutrition Study of Chinese adults - comments by Samuels. Journal of Nutritional, 9, 11-13.

33. Tarasoff, L. \& Kelly, M.F. (1993). Monosodium L-glutamate: A double-blind study and review. Journal of Food and Chemical Toxicology, 31, 1019-1035.

34. García, O.J.C., Moyano, C., Fonseca, J.L. \& Bellido, J. (1996). The Chinese restaurant syndrome. Journal of Medicine Clinical, 107(13), 518.

35. Yang, W.H., Drouin, M.A., Herbert, M., Mao, Y. \& Karsh, J. (1997). The monosodium glutamate symptom complex: assessment in a double-blind, placebo-controlled, randomized study. Journal of Allergy and Clinical Immunology, 99, 757-762.

36. Walker, R. \& Lupien, J.R. (2000). The safety evaluation of monosodium glutamate. Journal of Nutrition, 1049-1052.

А. В. Руцкая, Н. В. Гецько, И. Я. Криницкая ТЕРНОПОЛЬСКИЙ ГОСУДАРСТВЕННЫЙ МЕДИЦИНСКИЙ УНИВЕРСИТЕТ ИМЕНИ И. Я. ГОРБАЧЕВСКОГО

\section{ТОКСИЧЕСКОЕ ВОЗДЕЙСТВИЕ ГЛУТАМАТА НАТРИЯ НА ЖИВОЙ ОРГАНИЗМ (ОБЗОР ЛИТЕРАТУРЫ)}

\section{Резюме}

В статье проанализировано имеющиеся литературные данные по проблеме применения пищевых добавок в пищевой промышленности. По мнению многих ученых, уменьшение количества свежих пищевых продуктов, употребляемых в пищу, и увеличение искусственных добавок могут быть одной из причин повышения распространенности таких заболеваний, как рак, сахарный диабет, ожирение, депрессия и бронхиальная астма.

Количество пищевых добавок, применяемых в производстве пищевых продуктов в разных странах, достигает сегодня пятисот, не считая комбинированных добавок и ароматизаторов. Одной из самых распространенных пищевых добавок как в Украине, так и в Европе является глутамат натрия (E621). Исследования показали, что избыток глутамата натрия может провоцировать развитие гипертонии и инсультов, сахарного диабета, болезни Альцгеймера и аномалии развития нервной системы, эрозийных поражений слизистой оболочки желудка и увеличение массы тела.

На сегодняшний день нет достоверных данных, которые показывали бы, в каких дозах и в каких условиях глутамат натрия, употребляемый в пищу постоянно, вреден для здоровья. Существуют исследования о том, что прием глутамата натрия в количестве 3 г в день опасен для здоровья человека. Однако другие исследователи утверждают, что ежедневное введение крысам глутамата натрия даже в безопасных для здоровья человека дозах (15 и 30 мг/ка, что соответствует 1 и 2 г на среднестатистического человека), имеет токсическое воздействие.

Итак, опираясь на большое количество данных, можно утверждать, что сегодня происходит постоянное увеличение использования пищевых добавок в пищевой промышленности как экономически развитых, так и развивающихся стран. И поскольку пищевые добавки являются чужеродными для организма человека веществами (по химическому составу или количеству), особую актуальность приобретают исследования влияния пищевых добавок на состояние здоровья человека. Данных о биохимических и морфологических изменениях в основных системах и органах организма крайне мало, поэтому возникает необходимость детально изучить эту проблему. Кроме этого, стоит акцентировать внимание не только на исследовании установленных опасных доз пищевых добавок, но и на изучении молекулярных механизмов влияния "безопасных" (разрешенных) доз этих веществ на живой организм.

КЛЮЧЕВЫЕ СЛОВА: пищевые добавки; глутамат натрия; токсичность. 


\section{TOXIC IMPACT OF MONOSODIUM GLUTAMATE ON A LIVING ORGANISM (LITERATURE REVIEW)}

Summary

The article analyzes the available literature data on the problem of the food additives usage in the food industry. According to many scientists, reducing the amount of fresh foods that are eaten, and increasing of artificial additives may be one of reasons for increased prevalence of diseases such as cancer, diabetes mellitus, obesity, depression and asthma.

Number of food additives used in food industry in different countries, is up to five hundred today, not counting the combined additives and flavorings. One of the most common food additive in Ukraine and in Europe is monosodium glutamate (E-621). Studies have shown that excess of sodium glutamate intake can provoke the development of hypertension and stroke, diabetes mellitus, Alzheimer's disease and abnormalities of the nervous system development, erosive lesions of the mucous membrane of the stomach and weight gain.

There are no reliable data that showed in what doses and at what conditions monosodium glutamate which is used in foods constantly is harmful to health. On the one hand, there are studies that intake of monosodium glutamate in the dosage of 3 grams per day is dangerous to human health. However, other researchers argue that daily administration of sodium glutamate to rats even in safe for human health doses (15 and $30 \mathrm{mg} / \mathrm{kg}$ ), corresponding to 1 and 2 grams for the average adult person, has toxic effects.

Thus, based on the large amount of data can be argued that today there is a constant increase in the use of food additives in the food industry of an economically developed countries as well as countries with low intake. And because food additives are foreign substances to the human body (due to the chemical composition or number) investigation of their effect on human health has become relevant. Moreover, small number of data on biochemical and morphological changes in major organs and body systems dictate the need for a detailed study of the problem. In addition, it is necessary to focus not only on the study of established dangerous doses of food additives, but also to study the molecular mechanisms of these substances influence on the living body in "safe" (permitted) doses.

KEY WORDS: dietary additives; monosodium glutamate; toxicity.

Отримано 14.02.17

Адреса для листування: А. В. Руцька, Тернопільський державний медичний університет імені І. Я. Горбачевського, м. Волі, 1, Тернопіль, 46001, Україна, e-mail: nastya@tdmu.edu.ua. 